Article

\title{
Does the Pre-Ovulatory Pig Oviduct Rule Sperm Capacitation In Vivo Mediating Transcriptomics of Catsper Channels?
}

\author{
Cristina A. Martinez ${ }^{1, *(\mathbb{D})}$, Manuel Alvarez-Rodriguez ${ }^{1}\left(\mathbb{D}\right.$, Dominic $_{\text {Wright }}{ }^{2}$ and \\ Heriberto Rodriguez-Martinez ${ }^{1}$ (D) \\ 1 Department of Biomedical and Clinical Sciences (BKV), BKH/Obstetrics and Gynecology, \\ Faculty of Medicine and Health Sciences, Linköping University, SE-58185 Linköping, Sweden; \\ manuel.alvarez-rodriguez@liu.se (M.A.-R.); heriberto.rodriguez-martinez@liu.se (H.R.-M.) \\ 2 Department of Physics, Chemistry and Biology, Faculty of Science and Engineering; Linköping University, \\ SE-58183 Linköping, Sweden; dominic.wright@liu.se \\ * Correspondence: cristina.martinez-serrano@liu.se; Tel.: +34-678077708
}

Received: 15 February 2020; Accepted: 5 March 2020; Published: 7 March 2020

check for updates

\begin{abstract}
Spermatozoa need to conduct a series of biochemical changes termed capacitation in order to fertilize. In vivo, capacitation is sequentially achieved during sperm transport and interaction with the female genital tract, by mechanisms yet undisclosed in detail. However, when boar spermatozoa are stored in the tubal reservoir pre-ovulation, most appear to be in a non-capacitated state. This study aimed at deciphering the transcriptomics of capacitation-related genes in the pig pre-ovulatory oviduct, following the entry of semen or of sperm-free seminal plasma (SP). Ex-vivo samples of the utero-tubal junction (UTJ) and isthmus were examined with a microarray chip (GeneChip ${ }^{\circledR}$ Porcine Gene 1.0 ST Array, Thermo Fisher Scientific) followed by bioinformatics for enriched analysis of functional categories (GO terms) and restrictive statistics. The results confirmed that entry of semen or of relative amounts of sperm-free SP modifies gene expression of these segments, pre-ovulation. It further shows that enriched genes are differentially associated with pathways relating to sperm motility, acrosome reaction, single fertilization, and the regulation of signal transduction GO terms. In particular, the pre-ovulation oviduct stimulates the Catsper channels for sperm $\mathrm{Ca}^{2+}$ influx, with $A K A P S, C A T S P E R s$, and CABYR genes being positive regulators while PKIs and CRISP1 genes appear to be inhibitors of the process. We postulate that the stimulation of PKIs and CRISP1 genes in the pre-ovulation sperm reservoir/adjacent isthmus, mediated by SP, act to prevent premature massive capacitation prior to ovulation.
\end{abstract}

Keywords: capacitation; oviduct; sperm oviduct reservoir

\section{Introduction}

The complex nature of maternal-gamete communication has gained increased interest over the past decades. It is known that the signals provided by the gametes and interactions with the female genital tract are capable of rapidly influencing the local environment, stimulating a broad range of events towards successful fertilization and subsequent pregnancy [1,2]. These signals are critical in influencing a wide number of gamete functions such as final gamete maturation, gamete transport and survival, and are initiated by the gametes themselves immediately after ovulation or through mating/artificial insemination [3]. These events are all dependent upon the relay of the appropriate molecular signals between the maternal environment and the gametes. On the male side, after spermatozoa are deposited in the female genital tract, they have to overcome multiple physical barriers and complex interactions until they reach the site of fertilization at the mid-ampulla [4]. The fact 
that semen deposition elicits molecular alterations in the female genital tract has been previously described [5-8]. It appears to evoke an inflammatory response towards the acquisition of the so-called maternal state of immune tolerance [9]. A recent study has demonstrated the activation of a local immune response in the endometrium and the oviduct as rapidly as $24 \mathrm{~h}$ after semen or even seminal plasma (SP) has been deposited in the porcine female genital tract [10].

Understanding the mechanisms regulating uterine/oviduct-gamete interactions prior to fertilization has attracted particular interest in recent years because of its potential relationship with infertility, or even its relation to the subsequent embryo development [11,12]. It is known that inseminated spermatozoa must undergo functional modifications that render them competent to fertilize the oocyte, a process called "sperm capacitation" [13] discovered more than 60 years ago [14] but its mechanisms are still not known in detail. It is generally accepted that the functional changes achieved during sperm capacitation occur during two events. Firstly, spermatozoa display a hyperactivation of their motility, enabling them to detach from the isthmic reservoir and become free in the lumen, to be further transported to the site of fertilization. Secondly, when spermatozoa reach the oocyte, interact with the zona pellucida (ZP), and subsequently undergo the acrosome reaction [15]. Capacitation involves complex modification in the molecular landscape of the sperm plasma membrane [16,17]. These processes have been mimicked in vitro during assisted reproductive procedures by sperm incubation in well-defined culture media, resulting in adequate rates of sperm penetration through the ZP and fusion with the oolemma, though this does not always result in the formation of a viable zygote [18-20]. Moreover, boar spermatozoa in vitro display unpredictable acrosome disruption as well as inadequate sperm motility patterns, both contributing significantly to variable outcomes of in-vitro systems (IVF) [21]. To date, multiple methods have been carried out to achieve in vitro sperm capacitation, such as stimulation of the sperm cell's kinematics by the addition of bicarbonate to the culture medium. Bicarbonate is a major secretory component of the oviduct during capacitation and plays a pivotal role in facilitating the influx of $\mathrm{Ca}^{2+}$ through the sperm membrane [22], and it is widely reported as conditio sine qua non for sperm hyperactivation in vivo [23]. Moreover, seminal plasma (SP), which contains inhibitors of capacitation preventing sperm premature capacitation [24], is eliminated during in vitro fertilization [25].

In vitro selection of spermatozoa to improve IVF is unlikely to correspond to events occurring in vivo [19]. Under in vivo conditions, progressively motile spermatozoa are selected during their journey through the genital tract $[26,27]$ and most $\mathrm{SP}$ is removed from the sperm surface by interaction with the female (washing with intraluminal fluid, etc.) before arrival to the site of fertilization. Oviduct lining cells are further able to either promote or prevent capacitation in a time-specific manner to ensure the availability of sufficient numbers of functional spermatozoa once the ovulated oocytes reach the ampulla $[28,29]$. However, how the female tract participates in the capacitation process remains to be fully elucidated, particularly during the pre-ovulatory period, where capacitation is apparently prevented $[13,30,31]$.

Overall, increased knowledge of the gene pattern and molecular processes regulating the activity of the oviduct that contribute to successful fertilization could lead to a significant advance in reproductive assisted technologies. Therefore, the objective of this study was to decipher the transcriptomics of capacitation-related genes in the pig pre-ovulatory oviduct, mediated by the entry of semen or of solely sperm-free seminal plasma in an in vivo experimental layout.

\section{Results}

\subsection{Gene Expression is Altered in the Pre-Ovulatory Oviduct after Semen or Sperm-Free SP Exposure}

The Affymetrix Porcine GeneChip ${ }^{\circledR}$ (Thermo Fisher Scientific, Gothenburg, Sweden) was used for the transcriptomic analyses $24 \mathrm{~h}$ after semen (mating or P1-AI) or sperm-free (SP-P1 or SP-Ejac) exposure of the oviduct. Setting the fold change to $1 /-1$ and $p$-value to $<0.05$, the data analysis revealed a total of 1696 genes were differentially expressed (DEG) in the Utero-Tubal Junction (UTJ) and 1923 
genes were differentially expressed in the isthmus (Isth) after mating (M), and 1662 (UTJ) and 886 (Isth) were DEG after artificial insemination (P1-AI), compared to controls (non-inseminated) sows. Exposure to sperm-free SP modified the expression of fewer genes; 755 (UTJ) and 942 (Isth) (SP-P1), and 483 (UTJ) and 252 (Isth) (SP-Ejac). Figure 1 shows the numbers of oviduct genes up- or down-regulated among groups. Overall, mating seemed to promote the highest differences in gene expression followed by P1-AI, SP-P1, and SP-Ejac.
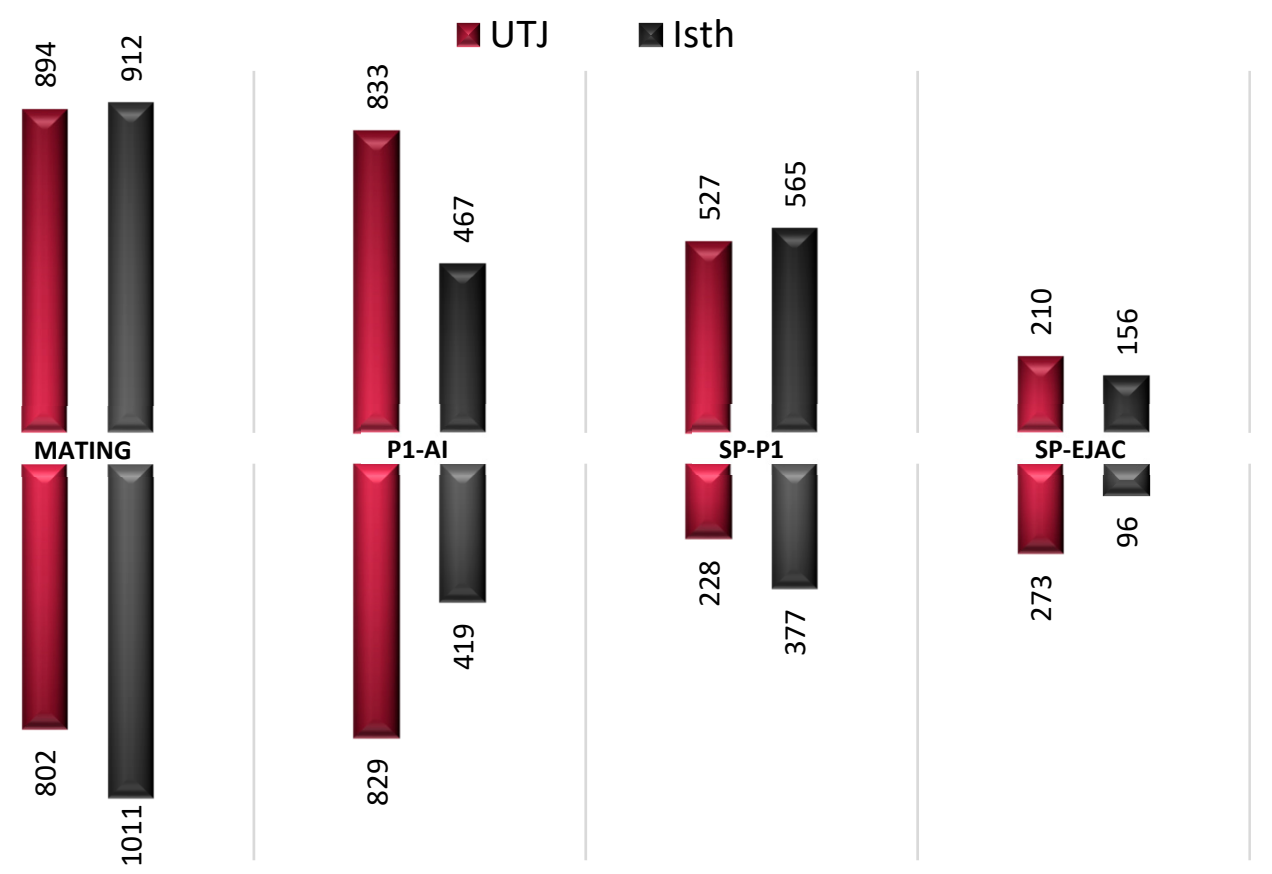

Figure 1. Differential expression (up- and down-regulation) of annotated genes. Treatment induced the differential expression of genes in all segments of the oviduct analyzed (Utero-tubal junction; UTJ, Isthmus; Isth). Mating: sow mated with a boar; P1-AI: sow artificially inseminated with the the sperm-peak ejaculate portion (P1) extended to $50 \mathrm{~mL}$ with BTS; SP-Ejac: sow cervically infused with sperm-free seminal plasma of the whole ejaculate $(50 \mathrm{~mL})$; SP-P1: sow cervically infused with sperm-free seminal plasma from pooled sperm-peak portion P1 $(50 \mathrm{~mL})$. All treatments were compared to Control (AI with $50 \mathrm{~mL}$ of BTS). The numbers represent the number of differentially expressed genes $(p$-value $<0.05)$.

2.2. Commonly Altered Genes between Pre-Ovulatory Oviduct Segments after Statistical Restrictive Analysis within Each Experimental Group

A more conservative statistical analysis was used to study the most robust data within each experimental group. The transcriptomic changes found were then plotted in a Venn diagram to visualize co-expressed genes shared among segments (Figure 2). Mating was the only group to show significantly altered transcripts using an False Discovery rate (FDR) $<0.05$ analysis (A), sharing eight altered genes between the oviductal segments. P1-AI and sperm-free groups were analyzed according to an adjusted $p$-value of $<0.01$. The largest number of genes that altered their expression, common to both oviductal segments were registered in the P1-AI treatment (B), followed by the SP-P1 (C). Exposure to SP from the entire ejaculate (SP-Ejac group) did not yield changes of expression in genes common to either mucosal segment (D). 
A

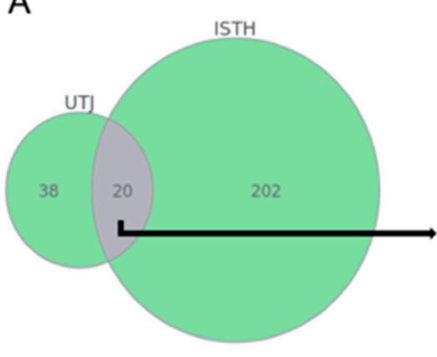

C

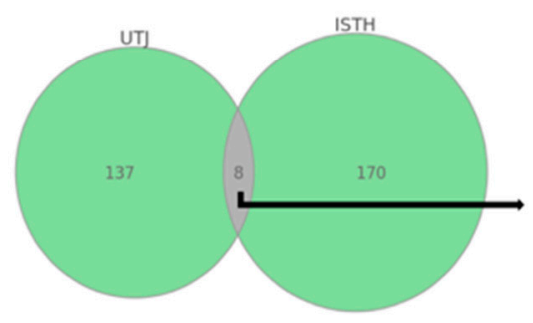

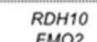
RDH10
FMO2 MYLIP
TTC39C
JAK2 JAK2
CTDSPL COL 16A1 SLC39A7 MAGED1
FKBP4 FKBP4
PLAUR LOC100737260 OLFML3 3 KIF2OA HMGCS SHAS2 $S R P X$ REXO2 VCAN

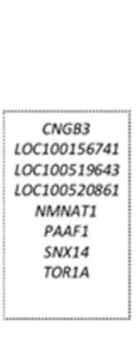

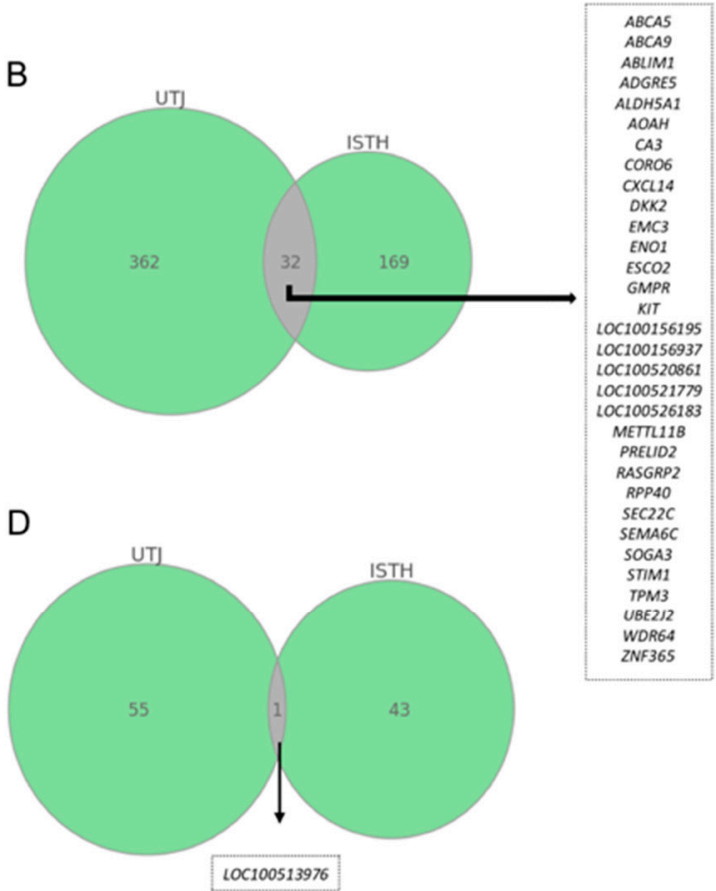

Figure 2. Venn diagram showing common altered genes among tissues within each treatment. Analysis of commonly altered transcripts among oviduct segments (UTJ: Utero-tubal junction; Isth: Isthmus;) after mating ((A); FDR < 0.05); artificial insemination from the sperm-peak ejaculate portion: P1-AI $((\mathbf{B}) ; p<0.01)$; exposure to seminal plasma from the sperm-peak ejaculate portion: SP-P1 ((C); $p<0.01)$; exposure to seminal plasma from the entire ejaculate: SP-Ejac $((\mathbf{D}) ; p<0.01)$. The numbers of genes altered in common are indicated at the intersections of the circles in the Venn diagram.

2.3. Analysis of Functional Categories: Enriched Tubal Genes During Pre-Ovulation are Differentially Associated with Sperm Motility, Acrosome Reaction, Single Fertilization, and Regulation of Signal Transduction

From the total gene set, we identified a subset of significantly differentially expressed transcripts involved in different biological processes that had potential roles in sperm capacitation. The transcripts of interest are shown in Table 1 (Mating: 20-UTJ; 17-Isth and P1-AI: 12-UTJ; 7-Isth groups) and Table 2 (SP-P1: 6-UTJ; 6-Isth and SP-Ejac: 3-UTJ; 1-Isth groups). The Database for Annotation, Visualization, and Integrated Discovery (DAVID 6.7) was used to annotate biological terms and processes preferentially represented in our study. The representation of those functional genes that were enriched for traits closely associated with sperm motility, acrosome reaction, single fertilization, and regulation of signal transduction, is shown in Figure 3. 
Table 1. Subset of altered transcripts potentially involved in sperm capacitation and/or fertilization in UTJ and Isth segments of the oviduct $24 \mathrm{~h}$ after mating or P1-AI.

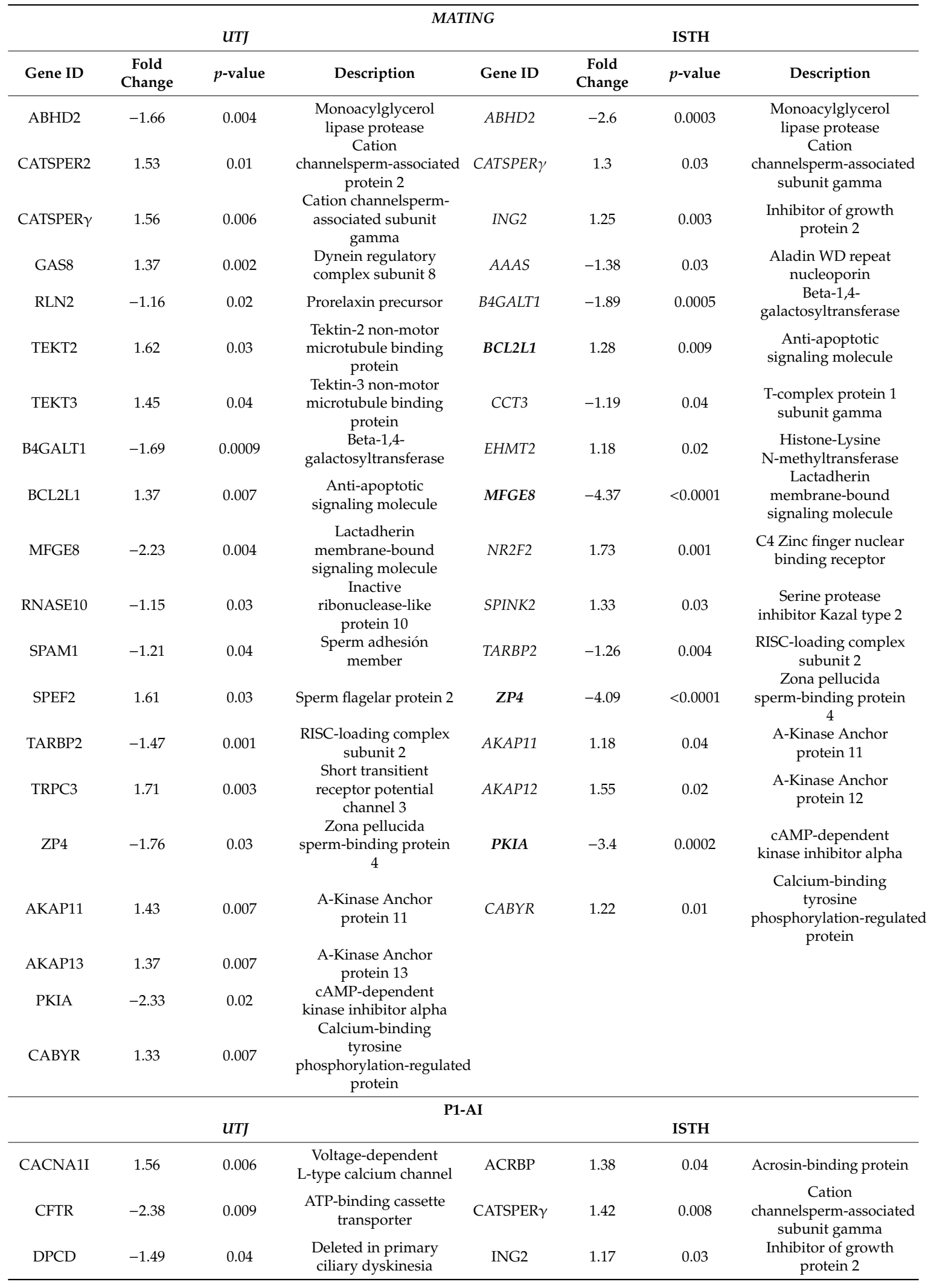


Table 1. Cont

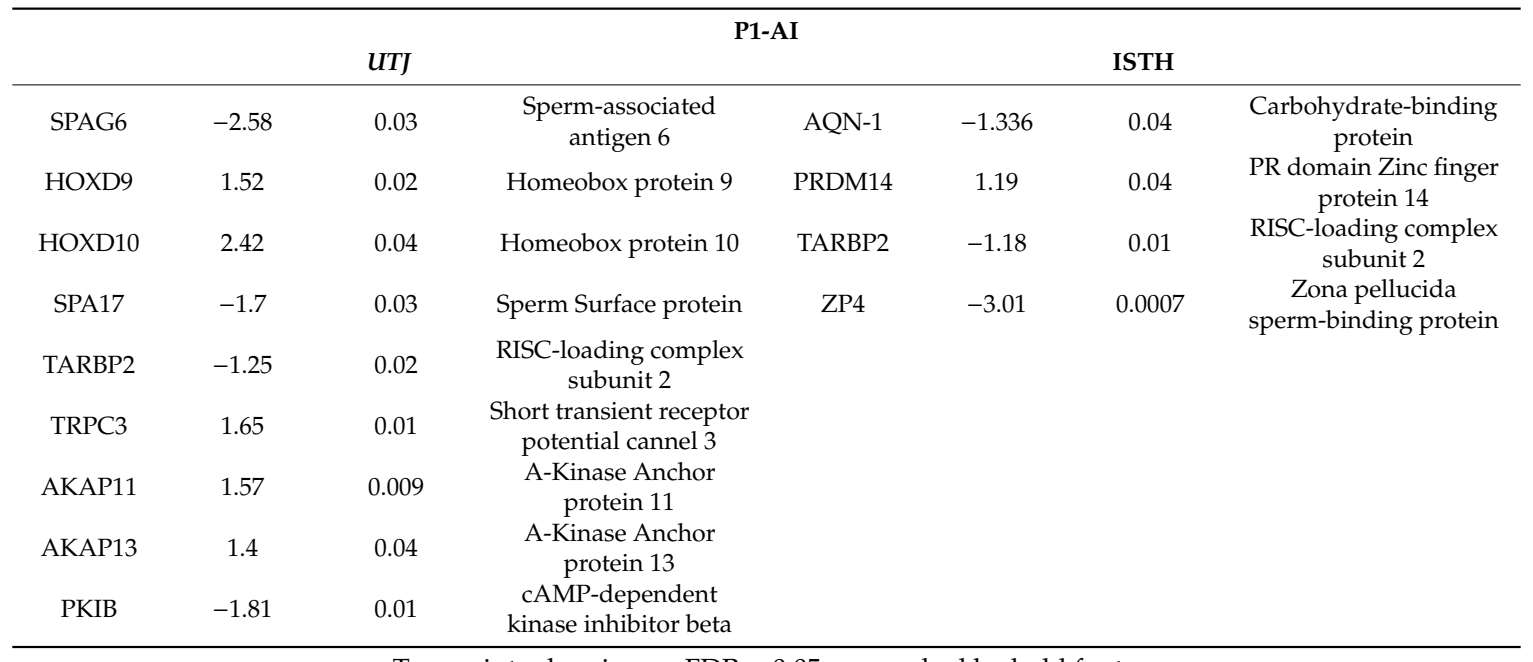

Transcripts showing an FDR $<0.05$ are marked by bold font.

Table 2. Subset of altered transcripts potentially involved in sperm capacitation and/or fertilization in UTJ and Isth segments of the oviduct $24 \mathrm{~h}$ after sperm-free seminal plasma (SP) exposal (SP-P1 or SP-Ejac).

\begin{tabular}{|c|c|c|c|c|c|c|c|}
\hline \multicolumn{8}{|c|}{$S P-P 1$} \\
\hline \multicolumn{4}{|c|}{ UTJ } & \multicolumn{4}{|c|}{ ISTH } \\
\hline Gene ID & $\begin{array}{l}\text { Fold } \\
\text { Change }\end{array}$ & $p$-value & Description & Gene ID & $\begin{array}{c}\text { Fold } \\
\text { Change }\end{array}$ & $p$-value & Description \\
\hline INSL6 & 1.39 & 0.0007 & Insulin-like 6 peptide & CACNA1D & 1.65 & 0.0008 & $\begin{array}{l}\text { Voltage-dependent } \\
\text { L-type calcium channel }\end{array}$ \\
\hline RNASE10 & -1.21 & 0.02 & $\begin{array}{c}\text { Inactive } \\
\text { ribonuclease-like } \\
\text { protein } 10\end{array}$ & TEKT3 & -1.14 & 0.04 & $\begin{array}{l}\text { Tektin-3 non-motor } \\
\text { microtubule binding } \\
\text { protein }\end{array}$ \\
\hline SLC26A8 & 1.28 & 0.02 & Anion transporter 1 & EHHMT2 & 1.16 & 0.04 & $\begin{array}{c}\text { Histone-Lysine } \\
\text { N-methyltransferase }\end{array}$ \\
\hline CRISP1 & 1.3 & 0.04 & $\begin{array}{l}\text { Custein-rich secretory } \\
\text { protein } 1\end{array}$ & HOXA11 & -1.31 & 0.02 & Homeobox protein A-11 \\
\hline PLCZ1 & 1.17 & 0.02 & $\begin{array}{l}\text { Calcium-binding } \\
\text { protein phospholipase } \\
\text { signaling molecule }\end{array}$ & SYCP2 & 1.92 & 0.01 & $\begin{array}{c}\text { Synaptonemal } \\
\text { complexprotein } 2\end{array}$ \\
\hline & & UTJ & & & & ISTH & \\
\hline CATSPER1 & -1.37 & 0.01 & $\begin{array}{c}\text { Cation } \\
\text { channelsperm-associated } \\
\text { protein } 1\end{array}$ & AAAS & 1.16 & 0.04 & $\begin{array}{l}\text { Aladin WD repeat } \\
\text { nucleoporin }\end{array}$ \\
\hline RLN2 & -1.22 & 0.04 & $\begin{array}{c}\text { Prorelaxin precursor } \\
\text { Inactive }\end{array}$ & & & & \\
\hline RNASE10 & -1.16 & 0.03 & $\begin{array}{c}\text { ribonuclease-like } \\
\text { protein } 10\end{array}$ & & & & \\
\hline
\end{tabular}



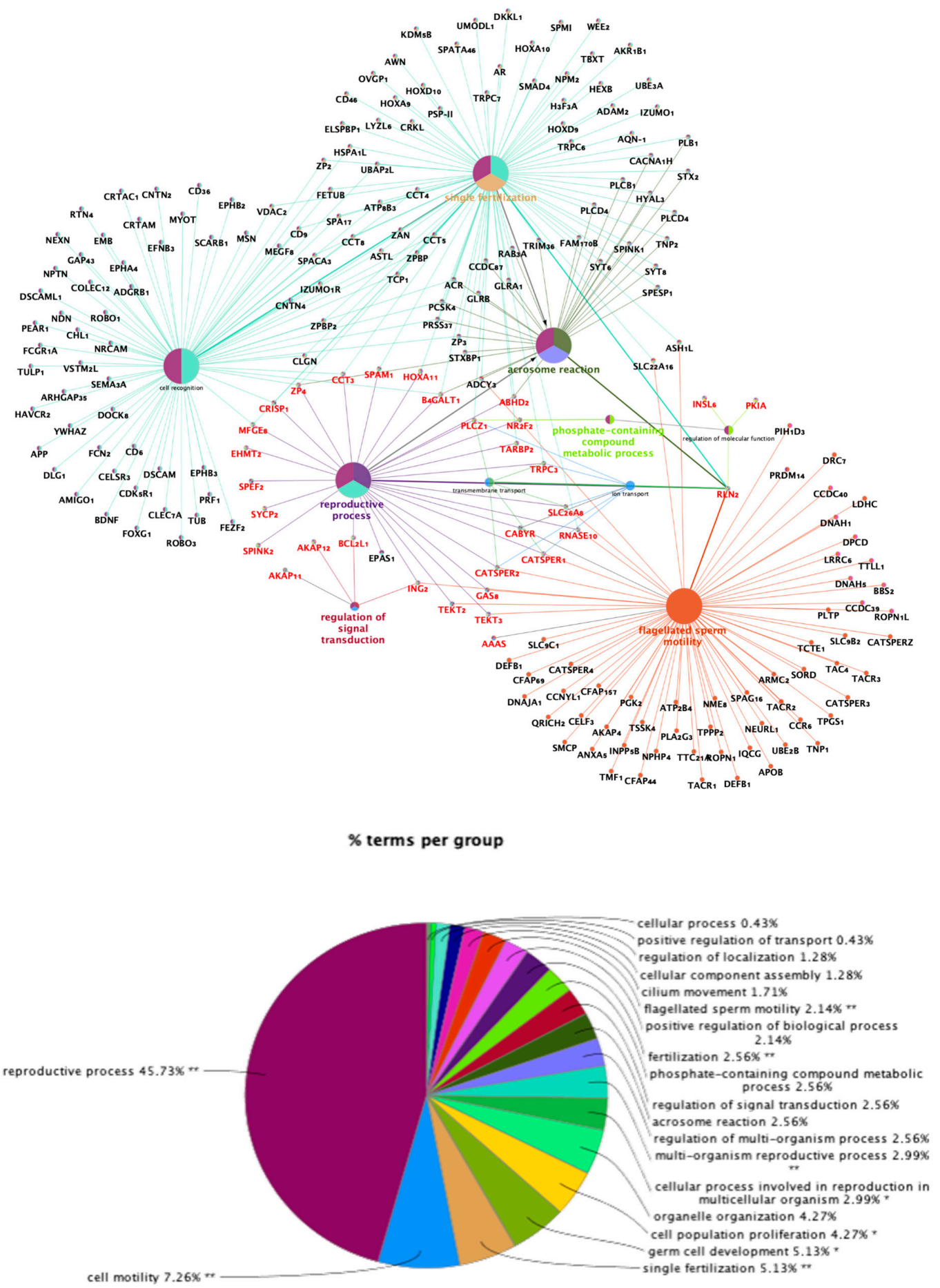

Figure 3. Schematic representation of functionally grouped terms. This network was created using the Cytoscape v3.0.0 application and the ClueGO+CluePedia (version 2.2.5) plug-in. Terms and their associated genes share the color. Genes marked in red are overrepresented in our study. The size of the nodes indicates the degree of significance, where the biggest nodes correspond to highest significance. The parameters included: biological process database (BP; date: 28.03.2019); GO tree levels, 2-6 (first level =0); minimum number of genes, 3; minimum percentage of genes, 4; GO term fusion; GO term connection restriction (kappa score), 0.4; GO term grouping, initial group size of 2 and 50\% for group merge; number of genes included in term $<100$. The resulting network was modified; that is, some redundant and noninformative terms were deleted and the network manually rearranged. 
2.4. Antagonistic Influences of Sperm- or Seminal Plasma on Pre-Ovulatory Oviductal Gene Expression for Sperm Capacitation Genes

We found a strong enrichment of genes in the pre-ovulatory pig oviduct associated with sperm capacitation through Catsper channels regulation, where semen (M or P1-AI), via the contents of spermatozoa, was inducing pro-capacitation responses while sperm-free SP (SP-P1 and SP-Ejac) appeared to be promoting anti-capacitation responses. Among the transcripts potentially involved in Catsper signaling, we found an up-regulation of CATSPER2 (UTJ) and CATSPER $\gamma$ (UTJ and Isth) in the mating group and an up-regulation of CATSPER $\gamma$ (Isth) in the P1-AI group (Table 1). On the other hand, we found CATSPER1 (UTJ) downregulated in sperm-free SP group (SP-Ejac) (Table 2). Also, several members of the $A K A P$ (A-Kinase anchoring proteins) family and the CABYR, CIRP1, ABDH2, CRISP1, and RNASE10 genes, all with potential roles in regulating Catsper channels were altered in our study (Tables 1 and 2). A model for the possible mechanisms of action of semen or SP, either from the entire ejaculate or its vanguard sperm-peak portion, in regulating oviduct signaling towards the activation or inactivation of these channels is presented in Figure 4. The model speculates that the pre-ovulation oviduct stimulates the receptors for sperm $\mathrm{Ca}^{2+}$ influx in a positive or a negative manner depending on whether it is exposed to spermatozoa or relative amounts of SP. In this case, AKAPS, CATSPERs, and CABYR genes are positive regulators while PKIs and CRISP1 genes are inhibitors of the Catsper channels.

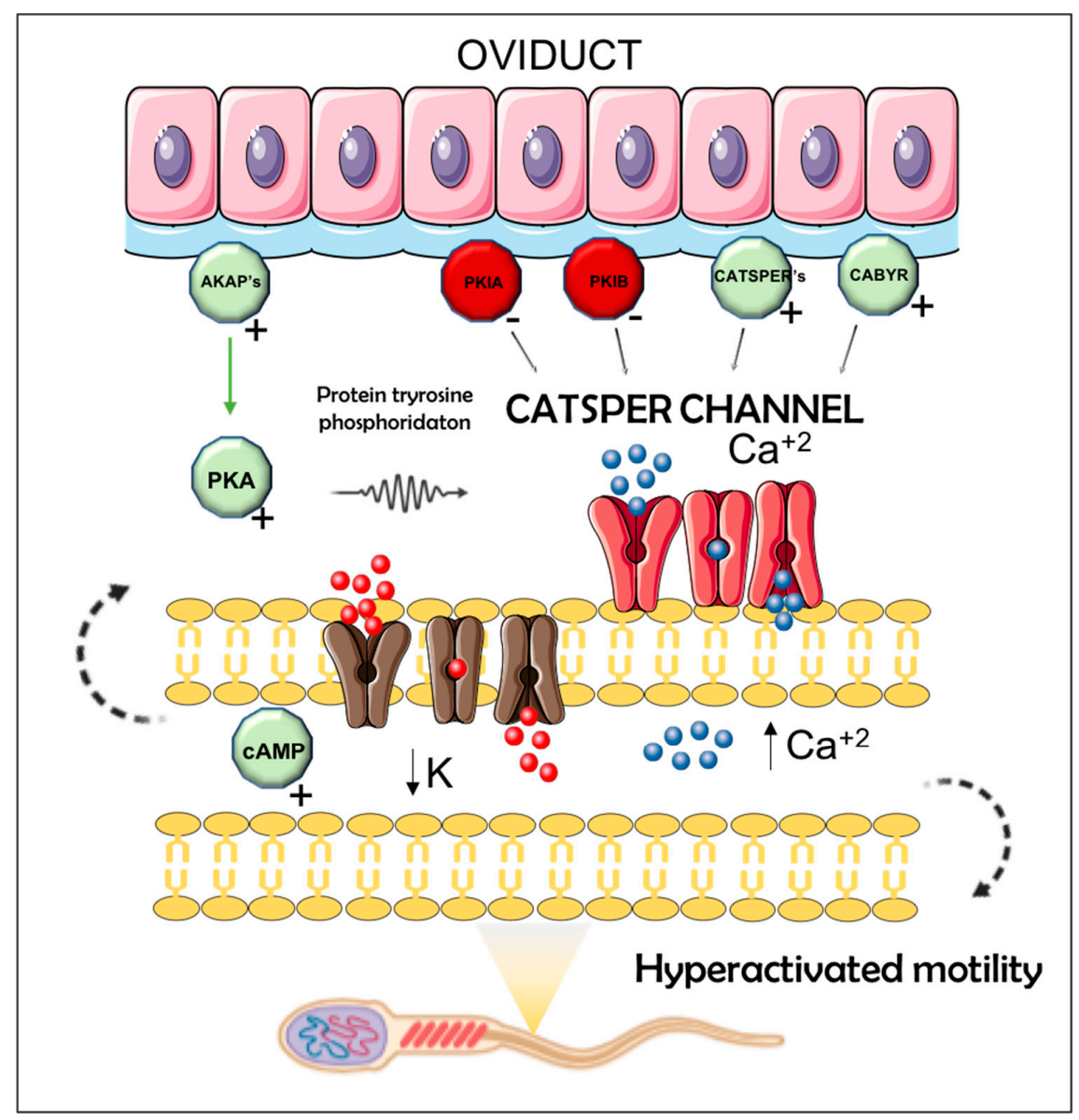

Figure 4. Model for sperm CatSper channel regulation in the oviduct. Possible signal transduction mechanisms of porcine sperm Ca2+ influx through the CatSper channels. The oviductal molecular signaling stimulate the receptors for spermatozoa $\mathrm{Ca} 2+$ influx in a positive or a negative manner depending on sperm or seminal plasma exposure. The different factors that are possibly affecting $\mathrm{Ca}^{2+}$ entry are depicted in the diagram, whereas AKAPs, CATSPERs, and CABYR genes are positive regulator of the Catsper channel, while PKIs and CRISP1 genes are inhibitors of the Catsper channels. 


\section{Discussion}

To achieve fertilization competence, a spermatozoon must undergo an as yet incompletely understood series of complex morphological and molecular maturational mechanisms, termed capacitation. This involves, among other processes, protein tyrosine phosphorylation and increments in intracellular calcium. The expression of hyperactivated motility and an ability to undergo the acrosome reaction serve, even when appearing independently from each other, as physiological end points to assess successful capacitation. In the present study, we report, to the best of our knowledge for the first time, how exposure to semen (Mating or AI) or to sperm-free SP (SP-P1 or SP-Ejac) influences the pattern of transcription of genes related to sperm capacitation in each of three segments of the pre-ovulatory pig oviduct (UTJ and Isthmus) $24 \mathrm{~h}$ after in vivo experimental exposure. In spermatozoa, capacitation, hyperactivation of motility, and acrosome reaction when exposed to ZP-proteins, are all mediated by increases in intracellular $\mathrm{Ca}^{2+}$, a basic key signaling element [23]. The change from basal, activated motility in ejaculated spermatozoa to a display of hyperactivated motility is triggered by a rapid rise of intracellular concentration of $\mathrm{Ca}^{2+}$ through the Catsper channel (sperm-specific cation channel) [32]. This multi-protein complex contains four pore-forming subunits (Catsper1-4) and five accessory subunits called $\beta, \delta, \varepsilon, \gamma$, and $\zeta$ encoded by at least nine genes in mammals $[33,34]$ and it is known to play a pivotal role in $\mathrm{Ca}^{2+}$ signaling by allowing the transport of $\mathrm{Ca}^{2+}$ into the cell [35], thereby influencing sperm motility in all species explored thus far, including the pig [36].

Genetic evidence shows that the function of Catsper channel proteins is indispensable for male fertility. In mice, knocking-out of any of the four Catsper genes results in male infertility, with phenotypic impairment including sperm motility, loss of hyperactivated motility and failure to penetrate the ZP [33]. In human, genetic lesions and altered expression profiles of Catsper genes have been clinically linked to astheno-teratospermia and male infertility [37]. Catsper proteins have been widely described in the principal piece of the sperm tail [36,38-40], CATSPER $\gamma$ and CATSPER $\delta$ subunits have been already identified in oviduct extracellular vesicles [41]. In the present study, we observed a higher expression of the CATSPER2 gene in the UTJ, the main sperm reservoir, after mating when compared to controls. Additionally, we found the Catsper channel auxiliary subunit gamma (CATSPER $\gamma$ ), necessary for Catsper channel function, to be upregulated in both oviduct segments explored (UTJ and ISTH) after mating but only in ISTH after AI with the vanguard sperm-peak fraction (P1). To this moment, the mechanisms by which oviduct cells regulates Catsper channels are poorly understood. Recent work suggests that Catsper channels, and therefore, the main entry of $\mathrm{Ca}^{2+}$ into the spermatozoa, are activated by protein kinase A (PKA) via cAMP-dependent tyrosine phosphorylation [42-44]. In this sense, it has been reported that association of PKA to cellular structures is triggered by A-Kinase anchoring proteins (AKAPs), which are a group of structurally diverse proteins binding to the regulatory subunit of protein kinase A (PKA) to transfer PKAs to subcellular locations [45]. Disruption of the PKA-AKAP interaction seems to affect sperm attributes associated to fertilizing capacity, suggesting that AKAPs may be part of a signal transduction pathway also likely to be involved in sperm hyperactivation [46,47]. In the present study, we observed an alteration of many AKAP-encoding genes among oviductal compartments and treatments. For instance, expression of $A K A P 11, A K A P 12$, and $A K A P 13$ were significantly higher in most tubal compartments in response to semen entry (mating or AI) compared to the saline control (mating: UTJ-AKAP11, AKAP13; Isth-AKAP11, AKAP12; AI: UTJ-AKAP11, AKAP13). Moreover, PKA inhibitors were found down-regulated in the UTJ and Isth (PKIA) after mating, and down-regulated in the UTJ (PKIB) after AI of the P1 ejaculate fraction. Altogether, these findings indicate that PKAs are actively regulated 24h after semen exposure, when spermatozoa are mostly stored in the oviductal reservoir [48] and where sperm hyperactivation or acrosome burst are not taking place. Sperm are prevented from hyperactivation by several mechanisms [29], with capacitation not completed in most spermatozoa [30]. Numerous different AKAPs have been identified from various tissues and species [49]. Most of these A-Kinase anchoring proteins have been exclusively identified in testicular germ cells and mature spermatozoa $[45,50]$. Here we report for the first time evidence of their presence in oviductal samples of 
domesticated pigs. Moreover, among proteins phosphorylated via PKA during capacitation, we found an upregulation of $C A B Y R$ (calcium-binding tyrosine phosphorylation-regulated gene) in the UTJ and Isth segments of the pig oviduct in response to semen exposure (mating). The protein encoded by this gene exhibits calcium-binding when phosphorylated during capacitation. It has been demonstrated that $C A B Y R$ increases during in vitro capacitation, and calcium binding to these acidic forms is abolished by alkaline phosphatase dephosphorylation [51]. Although it has been widely described in the principal piece of the sperm flagellum in several species [52-54], CABYR is expressed in human oviduct cells [55]. However, we could not find any evidence that this gene has been previously reported in the porcine oviduct. Our results suggest that $C A B Y R$ expression increases in the oviduct in response to sperm entry, possibly later contributing to changes in sperm flagellar movement and the display of hyperactivation. In the context of Catsper channels regulation, progesterone activates Catsper channels in human testicular and epididymal spermatozoa by binding to the sperm-membrane receptor; $\alpha / \beta$ hydrolase domain-containing protein 2 (ABHD2) which acts removing Catsper inhibitors to allow the channel to open [56-60]. However, it has been described in mouse spermatozoa that Catsper channels are activated by an increase in intracellular $\mathrm{pH}[61,62]$, and further they do not react to progesterone in vitro [56]; a situation similar to what our group recently reported for pig spermatozoa [36]. In the mouse, $A B H D 2$ does not seem essential for male fertility [56], an assumption which would be backed up by our results, considering that $A B D H 2$ was downregulated in the pig UTJ and Isth after mating compared to the controls. These overall findings would imply that the mechanics of sperm Catsper channels may differ between testicular/epididymal spermatozoa and ejaculated spermatozoa, or even among species. Moreover, inhibition of $A B H D 2$ has been shown to suppress porcine sperm release from oviduct reservoir [63], which might associate the downregulation of $A B H D 2$ found in this study with the fact that sperm release from oviductal cells was not fully achieved, considering the timing of tissue sampling (24h post-insemination, absence of spontaneous ovulation, and lack of pre-ovulatory progesterone surge $(\mathrm{P} 4=0.77 \pm 0.35 \mathrm{pg} / \mathrm{mL}$ in peripheral blood) $[30,48]$. An increase in progesterone concentrations immediately prior to and following ovulation facilitates the release of spermatozoa from the oviduct epithelium so that they can reach the site of fertilization [63], a process that occurs sequentially [48], rather than all at once (as it is usually achieved in vitro [19]). The reason why many of the transcripts described in the present work are highly overrepresented in the mating group in comparison with the P1-AI group, despite both containing spermatozoa, may be explained by the fact that they represent two different procedures, natural mating and artificial insemination (AI). Not only does natural mating involve a series of behavioral, mechanical, and neuro-hormonal components which are not matched by AI, but mating also implies deposition of a larger number of spermatozoa compared to the AI of the sperm-peak fraction we used, which only represents about $25 \%$ of the total sperm ejaculated $[64,65]$. Conventional AI, where semen doses are customarily extended, implies a further reduction of sperm numbers to 2.5-3 billion spermatozoa but also of the amount of SP inseminated, which is approximately 30 -times lower than that deposited during natural mating $[64,65]$. Such reductions, particularly of the amount of SP ought to be considered in the light of the present results. At first sight, sperm-free groups (SP-P1 and SP-Ejac) seemed to barely modify the molecular traits of the pig oviduct, as compared to the large numbers of DEGs elicited by sperm-containing treatments. However, we found some interesting results regarding the capacitation process. It is known that the SP contains 'decapacitation factors', mainly SP-proteins that coat and stabilize the sperm surface, likely to prevent premature capacitation, which are later removed to promote capacitation at a more appropriate time $[66,67]$. Seminal vesicles are believed to be responsible for the release of these decapacitating molecules that bind to the sperm membrane to inhibit capacitation. However, this phenomenon has been observed only in human and mice in vitro experiments that mixed capacitated spermatozoa with SP or candidate decapacitation factors [68-70]. In the pig, in vivo studies suggest that SP proteins are potentially involved in regulating sperm fertility [71,72].

Interestingly, we observed a down-regulation of CATSPER1 and CATSPER2 genes in oviduct cells when treated with sperm-free SP (SP-Ejac) in comparison with controls. Mutations of CATSPER1 and 
CATSPER2 genes have been related to male infertility in humans [73], and genetic deletion of any of the Catsper genes (CATSPER 1-4) resulted in loss of hyperactivated motility during the time of capacitation in mice $[32,74,75]$. Whether SP-molecules decapacitate spermatozoa through the inhibition of sperm Catsper signaling in the porcine oviduct has to the best of our knowledge, not been studied. In humans, although the mechanisms underlying these processes still remain to be fully elucidated, there is one molecule that appears to be involved in suppressing sperm motility and capacitation through the inhibition of Catsper channels: CRISP1 [76], the first identified member of the highly evolutionarily conserved cysteine-rich secretory protein (CRISP) family. The role of CRISP1 in the male tract has been extensively studied, where upon its binding to spermatozoa in the epididymis, it is carried with these cells into the female tract, acting as a decapacitating factor [77-81]. In mice, CRISP1 inhibited membrane depolarization as well as Catsper signaling in epididymal spermatozoa, confirming the ability of the protein to block this sperm $\mathrm{Ca}^{2+}$ channel [82]. However, only scattered information is available regarding the presence of this protein in the mammalian female tract [83]. Ernesto et al. [82] was the first group to provide evidence that CRISP1 is also expressed by oviduct cells and plays a role in fertilization by modulating hyperactivation, via modulation of key Catsper channels in human spermatozoa. The authors observed a reduction in sperm motility accompanied by an increase in CRISP1, which is in accordance with our findings, with CRISP1 being upregulated in UTJ exposed to sperm-free seminal plasma (SP-P1) which suggests that CRISP1 could be responsible for the inhibition of Catsper genes observed when oviduct cells were exposed to SP. The mechanism of action of CRISP1 towards Catsper inhibition is not clear. It has been proposed that CRISP1 has the ability to regulate protein tyrosine phosphorylation $[78,79,84,85]$, thus giving one potential explanatory mode of action when blocking Catsper channels. However, further studies are required to clarify how an eventual interaction between CRISP 1 and CATSPER functions. In addition, the RNASE10 gene, associated in murine epididymal spermatozoa to loss in their ability to capacitate [86], appeared down-regulated in the pig UTJ exposed to sperm-free SP (both SP-P1 and SP-Ejac). It is tempting to consider that the pig pre-ovulatory oviduct responds to the entry of spermatozoa and/or SP with changes in the expression of genes that are related to the control of sperm capacitation. However, we must stress that these responses are not directional nor simple, and that the treatments used include confounding factors that need to be considered. To start with, although this in-vivo experiment seems to demonstrate the influence of SP in regulating the capacitation process through molecular signaling in the oviduct, all treatments had SP, albeit in varying amounts. The major differences were: (i) the presence or absence of spermatozoa as well as (ii) the relative amount of SP-proteins present, considering the P1-fraction is the one containing the lowest amount of major SP proteins of the ejaculate [8]. Thus the presence of spermatozoa implies an up-regulation of AKAPs, CATSPERs, and CABYR genes, thus positively regulating the Catsper channel, while the SP downregulated PKIs and CRISP1 genes, which seem inhibitors of the Catsper channels is not an easy equation to handle. Although we have studied tubal samples, dissected to primarily sample the mucosa, it is impossible to fully ensure that all of the samples contained no spermatozoa. Whether sperm presence could per-se influence the gene expression is hard to establish, considering their relative transcriptomic inactivity.

Interestingly, in samples of which were incidentally also examined as comparison in this study (data not shown), the microarray platform revealed the alteration of many transcripts among semen-treatments in an upper segment of the oviduct (ampulla), despite the immense majority of spermatozoa are known to be located in the UTJ-isthmic reservoir during the time of sample collection (24 h after inseminations) [87]. Molecular signaling have been already studied in the site of fertilization, but at a later stage, post-ovulation, when both male and female gametes are transported to [88]. Some of the genes found upregulated in the ampulla at a post-ovulation stage [88] were found downregulated in the pre-ovulatory ampulla after mating (e.g., SPP1), while others appeared to be upregulated in in ampulla in both pre-and post-ovulatory periods (e.g., ITIH4 and TSHZ2). Additionally, in the ampullar samples we found an overall downregulation of fertilizing-related genes after mating and P1-AI, such as DNAJA1, DLD, and TEKT2, described before for their role in 
sperm maturation, motility and capacitation [89-91], or CCT2, CCT4, CCT7 (mating and AI), IZUMO1, $Z P 4$, and ZP2 (only mating), implicated in gamete recognition and sperm-binding to the ZP [92-95], suggesting that the oviduct itself is capable of suppressing the signals that enables spermatozoa to fertilize the oocyte, ensuring an adequate and efficient transition of these processes once the mature oocyte has reached the ampulla. Whether such findings are transient during pre-ovulation to change after ovulation has occurred, remains to be studied.

Regarding the presence of differential amounts of SP in all groups, the differences consisted in all SP-proteins being present in mating and its corresponding Ejac-SP, while the P1-AI and its SP-counterpart represented the SP fraction with the lowest contribution from the seminal vesicles, thus having the lowest amount of major SP proteins (spermadhesins) but the highest amounts of cauda epididymal fluid, which is considered the most effective milieu to maintain sperm quiescence, besides electrolyte composition [96]. In this regard, we could hypothesize that this scenario of highly abundant anti-capacitating factors masking pro-capacitation signals may be related to the fact that $24 \mathrm{~h}$ post insemination, most spermatozoa are maintained in a non-capacitated stage within the oviductal reservoir awaiting until ovulation takes place. It is concluded that the oviduct promotes, via a differential regulation of Catsper channels, pro- and anti-capacitation molecular responses. Whether the action of the genes particularly stimulated in the sperm reservoir/adjacent isthmus by the SP is to prevent premature massive capacitation prior to ovulation ought to be further studied.

\section{Materials and Methods}

\subsection{Experimental Design}

The transcriptomics of the pre/peri-ovulatory pig oviduct reservoir (UTJ and isthmus), was studied in a total of 20 pre-ovulatory sows, $24 \mathrm{~h}$ after the deposition of semen (i.e., spermatozoa and SP) or of sperm-free SP. Multiparous sows displaying standing oestrus in the presence of a boar were equally and at-random allotted to one of three groups, namely:

Control $(n=4)$, where females were cervically infused with $50 \mathrm{~mL}$ of the protein-free extender "Beltsville Thawing Solution" (BTS) [97],

Exposure to semen (spermatozoa and the accompanying SP) $(n=8)$, sub-divided as natural mating (M, $n=4)$, with sows each mated with a single male; or artificial cervical deposition (AI) of the sperm-peak ejaculate fraction e.g., the first $10 \mathrm{~mL}$ of the sperm-rich fraction (P1, extended with BTS to $50 \mathrm{~mL}$ ) (P1-AI, $n=4)$,

Exposure to sperm-free SP $(n=8)$, sub-divided as the SP of the entire ejaculate (SP-Ejac, $50 \mathrm{~mL}$, $n=4$ ) or only the SP from the P1 fraction (SP-P1, pool, $50 \mathrm{~mL}, n=4)$, either via cervical AI.

Samples from 2 different segments of the oviduct: the utero-tubal junction (UTJ) and isthmus (Isth) were surgically retrieved under general anesthesia, $24 \mathrm{~h}$ after the mating/AIs [10].

\subsection{Animal Management Including Ethics Statement}

Pigs of Swedish Landrace breed were recruited from a controlled breeding farm, as weaned sows (parity $1-3, n=20$ ) and young mature boars (9-11 months, $n=5$ ) of good semen quality ( $<100 \mathrm{~mL}$ volume, $>60 \times 10^{9}$ total sperm number, $>70 \%$ sperm motility, and $>75 \%$ morphologically normal-looking spermatozoa, controlled weekly) [10]. Throughout all experiments, animals were handled carefully to avoid any unnecessary stress. The animals were individually kept in separate pens at the Translational Medicine Centre (TMC/CBR-3) of Linköping University under controlled temperature and light regimes (12 h:12 h light/dark cycle). Pigs were fed with commercial feedstuff (Lantmännen, Stockholm, Sweden) according to national standards provided with water ad libitum and receiving the same management.

All animal husbandry and experimental handling was performed in compliance with the European Community (Directive 2010/63/EU) and current Swedish legislation (SJVFS 2017:40), being approved 
in advance by the "Regional Committee for Ethical Approval of Animal Experiments" (Linköpings Djurförsöksetiska nämnd) in Linköping, Sweden (permits no. 75-12 and no. ID1400).

\subsection{Semen Collection and SP Harvesting}

Ejaculates and the specific P1-fraction, collected using the gloved-hand method, with at least $70 \%$ motile and $75 \%$ morphologically normal-looking spermatozoa immediately after collection, were used. The SP was harvested either from the whole ejaculate or from the sperm-peak P1-fraction after double centrifugation at $1500 \times g$ for $10 \mathrm{~min}$, and microscopically checked for presence of spermatozoa. The harvested sperm-free crude SP was stored at $-20{ }^{\circ} \mathrm{C}$ until used.

\subsection{Handling of Sows}

Detection of estrus of the sows was performed twice daily, beginning one day after weaning, during their snout-to-snout contact with adjacent located mature boars, while testing for standing estrus reflex by applying back-pressure. When sows showed standing estrus reflex they were considered to be on the first day of behavioral estrus and then mated (M) or cervical AI with disposable commercial AI-catheters (Minitüb, Munich, Germany) (control, P1-AI, SP-P1, and PS-Ejac).

\subsection{Collection of Oviductal Samples}

All sows were subjected to mid-ventral laparotomies to collect the tissue samples $24 \mathrm{~h}$ after mating/inseminations (pre-/peri-ovulation period), as previously described [10]. Briefly, sows were sedated by the i.m. administration of a mixture of $5 \mathrm{mg}$ dexmeditomedine (Dexdomitor, Orion Pharma Animal Health, Sollentuna, Sweden) and $100 \mathrm{mg}$ tiletamine hydrochloride/zolazepam hydrochloride (Zoletil vet, Virbac A/S, Kolding, Denmark) followed by anesthesia induced i.v. with sodium thiopental (Abbot Scandinavia AB, Solna, Sweden, $7 \mathrm{mg} / \mathrm{kg} \mathrm{bw}$ ), and maintained with isoflurane (3.5-5\%, Baxter Medical AB, Kista, Sweden) administered via a tracheal cuffed tube by a close-circuit PVC-ventilator (Servo ventilator 900 D, SIEMENS-ELEMA AB, Solna, Sweden). The number of pre-ovulatory follicles per sow was $22.3 \pm 7.3$ (mean $\pm \mathrm{SD}$ ), without significant differences between sow-groups. Peripheral blood plasma was analyzed (ELISA) for progesterone $\left(\mathrm{P}_{4}\right)$ and estradiol $17 \AA\left(\mathrm{E}_{2}\right)$ contents, confirming the sows were in pre-/peri-ovulatory estrus $\left(\mathrm{P}_{4}=0.77 \pm 0.35 \mathrm{pg} / \mathrm{mL} ; \mathrm{E}_{2}\right.$ ranging 294.2-376.50 \pm $27.76 \mathrm{pg} / \mathrm{mL}, p>0.05$ among sows/groups). Oviductal segments (UTJ and Isth) were immediately retrieved, opened to expose the mucosa and stored at $-80^{\circ} \mathrm{C}$ in RNAlater (Ambion, Thermo Fisher Scientific Baltics UAB, Vilnius, Lithuania) until analyzed.

\subsection{Transcriptome Analysis}

Total RNA was isolated from tissue samples using Trizol reagent (Invitrogen, Carlsbad, CA, USA) and quality assessment was performed using an Agilent 2100 Bioanalyzer (Agilent Technologies, Santa Clara, CA, USA) according to the manufacturer's instructions. The RNA integrity number (RIN) values obtained were in the range of 8 to 10, which guarantied the homogeneity and high quality of the samples. Equal amounts of total RNA ( $250 \mathrm{ng}$ ) from each sample were used to make cDNA using GeneChip ${ }^{\circledR}$ Whole Transcript Plus reagent kit (Affymetrix, Santa Clara, CA, USA) following the manufacturer protocol. cDNA was then hybridized and loaded on the array chip (GeneChip ${ }^{\circledR}$ Porcine Gene 1.0 ST Array, Affymetrix Inc., 3420 Central Expressway, Santa Clara, CA 95051, USA), incubated at $45^{\circ} \mathrm{C}$ under 60 rotations per min, for $16 \mathrm{~h}$. The hybridized cartridge array chip was then unloaded and subjected to washing and staining using a GeneChip ${ }^{\circledR}$ Fluidics Station 450 (Affymetrix), to be finally scanned using the Affymetrix GeneChip ${ }^{\circledR}$ scanner GCS3000 [10].

\subsection{Analysis of Microarray Data and Bioinformatics}

The intensity data of each array chip was processed using the robust multi-array average (RMA) normalization, computing average intensity values by background adjustment, quantile normalization 
among arrays and finally $\log _{2}$ transformation to extract the expression values of each transcript in the probe set, as implemented in the official Transcriptome Analysis Console (TAC; version 4.0) from Affymetrix. The statistical analysis of the normalized gene expression data was performed using a linear model using the empirical Bayes' approach as implemented in the package "limma" was used to calculate differentially expressed transcripts using a Benjamini-Hochberg $(\mathrm{q}<0.05)$ correction to control for multiple testing to control type-I errors [98] and a fold change (FC) $>1$ or $<-1$.

\subsection{Enrichment Analysis}

The data was then analyzed using the Database for Annotation, Visualization and Integrated Discovery (DAVID 6.7). The differentially expressed genes $(p<0.05)$ were screened for additional molecular functions with the protein knowledge base of the UniProt Consortium [99]. Graphical illustration of overrepresented GO terms was produced with the Cytoscape v3.0.0 application CluePedia v2.0.3 [100]. Schematic representation of Catsper channels regulation was performed with Biorender ${ }^{\circledR}$ and SmarArt ${ }^{\circledR}$ softwares.

\section{Conclusions}

Altogether, the present findings point out that the presence of spermatozoa or of relative amounts of SP in the pre-ovulatory pig oviduct promotes pro- and anti-capacitation molecular responses via a differential regulation of Catsper channels. It is postulated that genes particularly stimulated in the sperm reservoir/adjacent isthmus by the SP would be to prevent premature massive capacitation prior to ovulation.

Author Contributions: Conceptualization, H.R.-M., D.W., M.R., and M.A.-R.; methodology, C.A.M., M.A.-R., D.W., and H.R.-M.; software, C.A.M. and M.A.-R.; validation, C.A.M.; data curation, C.A.M.; writing-original draft preparation, C.A.M.; writing—review and editing, C.A.M., M.A.-R., D.W., and H.R.-M.; visualization, C.A.M.; supervision, H.R.-M.; project administration, H.R.-M.; funding acquisition, H.R.-M., D.W., and M.A.-R. All authors have read and agreed to the published version of the manuscript.

Funding: This research was funded by the Research Council FORMAS, Stockholm (Project 2017-00946 and Project 2019-00288), the Swedish Research Council (Vetenskapsrådet, VR; project 2015-05919), and the Seneca Foundation (20780/PD/18) Murcia (Spain).

Acknowledgments: To CBR-LIU personnel for help with the handling of animals. To Annette Molbaek and Åsa Schippert, from the genomics Core Facility at LiU for expert assistance when running the microarrays.

Conflicts of Interest: The authors declare no conflict of interest. The funders had no role in the design of the study; in the collection, analyses, or interpretation of data; in the writing of the manuscript, or in the decision to publish the results.

\section{References}

1. Han, Y.; Biswas, D.; Yoon, J.D.; Jeon, Y.; Hyun, S.H. Effect of porcine uterus as ex vivo model of fertilizing ability and gene expression pattern on blastocysts. Theriogenology 2019, 129, 146-153. [CrossRef]

2. Georgiou, A.S.; Snijders, A.P.L.; Sostaric, E.; Aflatoonian, R.; Vazquez, J.L.; Vazquez, J.M.; Roca, J.; Martinez, E.A.; Wright, P.C.; Fazeli, A. Modulation of the oviductal environment by gametes. J. Proteome Res. 2007, 6, 4656-4666. [CrossRef]

3. Rizos, D.; Maillo, V.; Sanchez-Calabuig, M.-J.; Lonergan, P. The Consequences of Maternal-Embryonic Cross Talk During the Periconception Period on Subsequent Embryonic Development. Adv. Exp. Med. Biol. 2017, 1014, 69-86.

4. Hawk, H.W. Sperm survival and transport in the female reproductive tract. J. Dairy Sci. 1983, 66, 2645-2660. [CrossRef]

5. Alminana, C.; Caballero, I.; Heath, P.R.; Maleki-Dizaji, S.; Parrilla, I.; Cuello, C.; Gil, M.A.; Vazquez, J.L.; Vazquez, J.M.; Roca, J.; et al. The battle of the sexes starts in the oviduct: Modulation of oviductal transcriptome by X and Y-bearing spermatozoa. BMC Genom. 2014, 15, 293. [CrossRef] [PubMed] 
6. Waberski, D.; Schafer, J.; Bolling, A.; Scheld, M.; Henning, H.; Hambruch, N.; Schuberth, H.-J.; Pfarrer, C.; Wrenzycki, C.; Hunter, R.H.F. Seminal plasma modulates the immune-cytokine network in the porcine uterine tissue and pre-ovulatory follicles. PLoS ONE 2018, 13, e0202654. [CrossRef] [PubMed]

7. Fazeli, A.; Affara, N.A.; Hubank, M.; Holt, W.V. Sperm-induced modification of the oviductal gene expression profile after natural insemination in mice. Biol. Reprod. 2004, 71, 60-65. [CrossRef] [PubMed]

8. Rodriguez-Martinez, H.; Kvist, U.; Saravia, F.; Wallgren, M.; Johannisson, A.; Sanz, L.; Pena, FJ.; Martinez, E.A.; Roca, J.; Vazquez, J.M.; et al. The physiological roles of the boar ejaculate. Soc. Reprod. Fertil. Suppl. 2009, 66, 1-21.

9. Robertson, S.A.; Sharkey, D.J. The role of semen in induction of maternal immune tolerance to pregnancy. Semin. Immunol. 2001, 13, 243-254. [CrossRef]

10. Alvarez-Rodriguez, M.; Atikuzzaman, M.; Venhoranta, H.; Wright, D.; Rodriguez-Martinez, H. Expression of Immune Regulatory Genes in the Porcine Internal Genital Tract Is Differentially Triggered by Spermatozoa and Seminal Plasma. Int. J. Mol. Sci. 2019, 20, 513. [CrossRef]

11. Li, S.; Winuthayanon, W. Oviduct: Roles in fertilization and early embryo development. J. Endocrinol. 2017, 232, R1-R26. [CrossRef] [PubMed]

12. Edgell, T.A.; Evans, J.; Lazzaro, L.; Boyes, K.; Sridhar, M.; Catt, S.; Rombauts, L.J.F.; Vollenhoven, B.J.; Salamonsen, L.A. Assessment of potential biomarkers of pre-receptive and receptive endometrium in uterine fluid and a functional evaluation of the potential role of CSF3 in fertility. Cytokine 2018, 111, 222-229. [CrossRef] [PubMed]

13. Hunter, R.H.F.; Rodriguez-Martinez, H. Capacitation of mammalian spermatozoa in vivo, with a specific focus on events in the Fallopian tubes. Mol. Reprod. Dev. 2004, 67, 243-250. [CrossRef] [PubMed]

14. AUSTIN, C.R. The capacitation of the mammalian sperm. Nature 1952, 170, 326. [CrossRef] [PubMed]

15. Ho, H.C.; Suarez, S.S. Hyperactivation of mammalian spermatozoa: Function and regulation. Reproduction 2001, 122, 519-526. [CrossRef] [PubMed]

16. Visconti, P.E.; Westbrook, V.A.; Chertihin, O.; Demarco, I.; Sleight, S.; Diekman, A.B. Novel signaling pathways involved in sperm acquisition of fertilizing capacity. J. Reprod. Immunol. 2002, 53, 133-150. [CrossRef]

17. Jin, S.-K.; Yang, W.-X. Factors and pathways involved in capacitation: How are they regulated? Oncotarget 2017, 8, 3600-3627. [CrossRef]

18. Niemann, H.; Rath, D. Progress in reproductive biotechnology in swine. Theriogenology 2001, 56, 1291-1304. [CrossRef]

19. Hunter, R.H.F.; Rodriguez-Martinez, H. Analysing mammalian fertilisation: Reservations and potential pitfalls with an in vitro approach. Zygote 2002, 10,11-15. [CrossRef]

20. Bergqvist, A.-S.; Ballester, J.; Johannisson, A.; Hernandez, M.; Lundeheim, N.; Rodriguez-Martinez, H. In vitro capacitation of bull spermatozoa by oviductal fluid and its components. Zygote 2006, 14, 259-273. [CrossRef]

21. Morrell, J.M.; Rodriguez-Martinez, H. Practical applications of sperm selection techniques as a tool for improving reproductive efficiency. Vet. Med. Int. 2010, 2011. [CrossRef] [PubMed]

22. Soriano-Úbeda, C.; Romero-Aguirregomezcorta, J.; Matás, C.; Visconti, P.E.; García-Vázquez, F.A. Manipulation of bicarbonate concentration in sperm capacitation media improvesin vitro fertilisation output in porcine species. J. Anim. Sci. Biotechnol. 2019, 11, 19.

23. Darszon, A.; Nishigaki, T.; Beltran, C.; Trevino, C.L. Calcium channels in the development, maturation, and function of spermatozoa. Physiol. Rev. 2011, 91, 1305-1355. [CrossRef] [PubMed]

24. Bailey, J.L. Factors regulating sperm capacitation. Syst. Biol. Reprod. Med. 2010, 56, 334-348. [CrossRef] [PubMed]

25. Suzuki, K.; Asano, A.; Eriksson, B.; Niwa, K.; Nagai, T.; Rodriguez-Martinez, H. Capacitation status and in vitro fertility of boar spermatozoa: Effects of seminal plasma, cumulus-oocyte-complexes-conditioned medium and hyaluronan. Int. J. Androl. 2002, 25, 84-93. [CrossRef]

26. Aitken, R.J.; Nixon, B. Sperm capacitation: A distant landscape glimpsed but unexplored. Mol. Hum. Reprod. 2013, 19, 785-793. [CrossRef]

27. Rodriguez-Martinez, H.; Tienthai, P.; Atikuzzaman, M.; Vicente-Carrillo, A.; Ruber, M.; Alvarez-Rodriguez, M. The ubiquitous hyaluronan: Functionally implicated in the oviduct? Theriogenology 2016, 86, 182-186. [CrossRef] 
28. Boilard, M.; Bailey, J.; Collin, S.; Dufour, M.; Sirard, M.-A. Effect of bovine oviduct epithelial cell apical plasma membranes on sperm function assessed by a novel flow cytometric approach. Biol. Reprod. 2002, 67, 1125-1132. [CrossRef]

29. Rodriguez-Martinez, H. Role of the oviduct in sperm capacitation. Theriogenology 2007, 68 (Suppl. 1), S138-S146. [CrossRef]

30. Tienthai, P.; Johannisson, A.; Rodriguez-Martinez, H. Sperm capacitation in the porcine oviduct. Anim. Reprod. Sci. 2004, 80, 131-146. [CrossRef]

31. Rodriguez-Martinez, H.; Tienthai, P.; Suzuki, K.; Funahashi, H.; Ekwall, H.; Johannisson, A. Involvement of oviduct in sperm capacitation and oocyte development in pigs. Reprod. Suppl. 2001, 58, 129-145. [PubMed]

32. Carlson, A.E.; Westenbroek, R.E.; Quill, T.; Ren, D.; Clapham, D.E.; Hille, B.; Garbers, D.L.; Babcock, D.F. CatSper1 required for evoked $\mathrm{Ca} 2+$ entry and control of flagellar function in sperm. Proc. Natl. Acad. Sci. USA 2003, 100, 14864-14868. [CrossRef] [PubMed]

33. Sun, X.-H.; Zhu, Y.-Y.; Wang, L.; Liu, H.-L.; Ling, Y.; Li, Z.-L.; Sun, L.-B. The Catsper channel and its roles in male fertility: A systematic review. Reprod. Biol. Endocrinol. 2017, 15, 65. [CrossRef] [PubMed]

34. Navarro, B.; Kirichok, Y.; Chung, J.-J.; Clapham, D.E. Ion channels that control fertility in mammalian spermatozoa. Int. J. Dev. Biol. 2008, 52, 607-613. [CrossRef] [PubMed]

35. Kirichok, Y.; Navarro, B.; Clapham, D.E. Whole-cell patch-clamp measurements of spermatozoa reveal an alkaline-activated Ca2+ channel. Nature 2006, 439, 737-740. [CrossRef]

36. Vicente-Carrillo, A.; Alvarez-Rodriguez, M.; Rodriguez-Martinez, H. The CatSper channel modulates boar sperm motility during capacitation. Reprod. Biol. 2017, 17, 69-78. [CrossRef]

37. Avidan, N.; Tamary, H.; Dgany, O.; Cattan, D.; Pariente, A.; Thulliez, M.; Borot, N.; Moati, L.; Barthelme, A.; Shalmon, L.; et al. CATSPER2, a human autosomal nonsyndromic male infertility gene. Eur. J. Hum. Genet. 2003, 11, 497-502. [CrossRef]

38. Lobley, A.; Pierron, V.; Reynolds, L.; Allen, L.; Michalovich, D. Identification of human and mouse CatSper3 and CatSper4 genes: Characterisation of a common interaction domain and evidence for expression in testis. Reprod. Biol. Endocrinol. 2003, 1, 53. [CrossRef]

39. Liu, J.; Xia, J.; Cho, K.-H.; Clapham, D.E.; Ren, D. CatSperbeta, a novel transmembrane protein in the CatSper channel complex. J. Biol. Chem. 2007, 282, 18945-18952. [CrossRef]

40. Marquez, B.; Ignotz, G.; Suarez, S.S. Contributions of extracellular and intracellular Ca2+ to regulation of sperm motility: Release of intracellular stores can hyperactivate CatSper1 and CatSper2 null sperm. Dev. Biol. 2007, 303, 214-221. [CrossRef]

41. Alminana, C.; Tsikis, G.; Labas, V.; Uzbekov, R.; da Silveira, J.C.; Bauersachs, S.; Mermillod, P. Deciphering the oviductal extracellular vesicles content across the estrous cycle: Implications for the gametes-oviduct interactions and the environment of the potential embryo. BMC Genom. 2018, 19, 622. [CrossRef] [PubMed]

42. Matamoros-Volante, A.; Moreno-Irusta, A.; Torres-Rodriguez, P.; Giojalas, L.; Gervasi, M.G.; Visconti, P.E.; Trevino, C.L. Semi-automatized segmentation method using image-based flow cytometry to study sperm physiology: The case of capacitation-induced tyrosine phosphorylation. Mol. Hum. Reprod. 2018, 24, 64-73. [CrossRef] [PubMed]

43. Orta, G.; de la Vega-Beltran, J.L.; Martin-Hidalgo, D.; Santi, C.M.; Visconti, P.E.; Darszon, A. CatSper channels are regulated by protein kinase A. J. Biol. Chem. 2018, 293, 16830-16841. [CrossRef]

44. O’Brien, E.D.; Krapf, D.; Cabada, M.O.; Visconti, P.E.; Arranz, S.E. Transmembrane adenylyl cyclase regulates amphibian sperm motility through protein kinase A activation. Dev. Biol. 2011, 350, 80-88. [CrossRef]

45. Reinton, N.; Collas, P.; Haugen, T.B.; Skalhegg, B.S.; Hansson, V.; Jahnsen, T.; Tasken, K. Localization of a novel human A-kinase-anchoring protein, hAKAP220, during spermatogenesis. Dev. Biol. 2000, 223, $194-204$. [CrossRef] [PubMed]

46. Ficarro, S.; Chertihin, O.; Westbrook, V.A.; White, F.; Jayes, F.; Kalab, P.; Marto, J.A.; Shabanowitz, J.; Herr, J.C.; Hunt, D.F.; et al. Phosphoproteome analysis of capacitated human sperm. Evidence of tyrosine phosphorylation of a kinase-anchoring protein 3 and valosin-containing protein/p97 during capacitation. J. Biol. Chem. 2003, 278, 11579-11589. [CrossRef] [PubMed]

47. Stival, C.; Ritagliati, C.; Xu, X.; Gervasi, M.G.; Luque, G.M.; Baro Graf, C.; De la Vega-Beltran, J.L.; Torres, N.; Darszon, A.; Krapf, D.; et al. Disruption of protein kinase A localization induces acrosomal exocytosis in capacitated mouse sperm. J. Biol. Chem. 2018, 293, 9435-9447. [CrossRef] 
48. Mburu, J.N.; Einarsson, S.; Lundeheim, N.; Rodriguez-Martinez, H. Distribution, number and membrane integrity of spermatozoa in the pig oviduct in relation to spontaneous ovulation. Anim. Reprod. Sci. 1996, 45, 109-121. [CrossRef]

49. Colledge, M.; Scott, J.D. AKAPs: From structure to function. Trends Cell Biol. 1999, 9, 216-221. [CrossRef]

50. Feliciello, A.; Rubin, C.S.; Avvedimento, E.V.; Gottesman, M.E. Expression of a kinase anchor protein 121 is regulated by hormones in thyroid and testicular germ cells. J. Biol. Chem. 1998, 273, 23361-23366. [CrossRef]

51. Liu, S.-L.; Ni, B.; Wang, X.-W.; Huo, W.-Q.; Zhang, J.; Tian, Z.-Q.; Huang, Z.-M.; Tian, Y.; Tang, J.; Zheng, Y.-H.; et al. FSCB phosphorylation in mouse spermatozoa capacitation. BMB Rep. 2011, 44, 541-546. [CrossRef] [PubMed]

52. Naaby-Hansen, S. Functional and immunological analysis of the human sperm proteome. Dan. Med. J. 2012, 59, B4414. [PubMed]

53. Li, Y.-F.; He, W.; Jha, K.N.; Klotz, K.; Kim, Y.-H.; Mandal, A.; Pulido, S.; Digilio, L.; Flickinger, C.J.; Herr, J.C. FSCB, a novel protein kinase A-phosphorylated calcium-binding protein, is a CABYR-binding partner involved in late steps of fibrous sheath biogenesis. J. Biol. Chem. 2007, 282, 34104-34119. [CrossRef] [PubMed]

54. Zhang, X.; Chen, M.; Yu, R.; Liu, B.; Tian, Z.; Liu, S. FSCB phosphorylation regulates mouse spermatozoa capacitation through suppressing SUMOylation of ROPN1/ROPN1L. Am. J. Transl. Res. 2016, 8, 2776-2782.

55. Newell, A.E.H.; Fiedler, S.E.; Ruan, J.M.; Pan, J.; Wang, P.J.; Deininger, J.; Corless, C.L.; Carr, D.W. Protein kinase A RII-like (R2D2) proteins exhibit differential localization and AKAP interaction. Cell Motil. Cytoskeleton 2008, 65, 539-552. [CrossRef]

56. Lishko, P.V.; Botchkina, I.L.; Kirichok, Y. Progesterone activates the principal Ca2+ channel of human sperm. Nature 2011, 471, 387-391. [CrossRef]

57. Blackmore, P.F.; Beebe, S.J.; Danforth, D.R.; Alexander, N. Progesterone and 17 alpha-hydroxyprogesterone. Novel stimulators of calcium influx in human sperm. J. Biol. Chem. 1990, 265, 1376-1380.

58. Park, K.-H.; Kim, B.-J.; Kang, J.; Nam, T.-S.; Lim, J.M.; Kim, H.T.; Park, J.K.; Kim, Y.G.; Chae, S.-W.; Kim, U.-H. $\mathrm{Ca} 2+$ signaling tools acquired from prostasomes are required for progesterone-induced sperm motility. Sci. Signal. 2011, 4, ra31. [CrossRef]

59. Sagare-Patil, V.; Vernekar, M.; Galvankar, M.; Modi, D. Progesterone utilizes the PI3K-AKT pathway in human spermatozoa to regulate motility and hyperactivation but not acrosome reaction. Mol. Cell. Endocrinol. 2013, 374, 82-91. [CrossRef]

60. Tamburrino, L.; Marchiani, S.; Minetti, F.; Forti, G.; Muratori, M.; Baldi, E. The CatSper calcium channel in human sperm: Relation with motility and involvement in progesterone-induced acrosome reaction. Hum. Reprod. 2014, 29, 418-428. [CrossRef]

61. Miller, M.R.; Mansell, S.A.; Meyers, S.A.; Lishko, P.V. Flagellar ion channels of sperm: Similarities and differences between species. Cell Calcium 2015, 58, 105-113. [CrossRef] [PubMed]

62. Hwang, J.Y.; Mannowetz, N.; Zhang, Y.; Everley, R.A.; Gygi, S.P.; Bewersdorf, J.; Lishko, P.V.; Chung, J.-J. Dual Sensing of Physiologic $\mathrm{pH}$ and Calcium by EFCAB9 Regulates Sperm Motility. Cell 2019, 177, 1480-1494. [CrossRef] [PubMed]

63. Machado, S.A.; Sharif, M.; Wang, H.; Bovin, N.; Miller, D.J. Release of Porcine Sperm from Oviduct Cells is Stimulated by Progesterone and Requires CatSper. Sci. Rep. 2019, 9. [CrossRef] [PubMed]

64. Knox, R.V. Artificial insemination in pigs today. Theriogenology 2016, 85, 83-93. [CrossRef]

65. Martinez, E.A.; Vazquez, J.M.; Roca, J.; Lucas, X.; Gil, M.A.; Vazquez, J.L. Deep intrauterine insemination and embryo transfer in pigs. Reprod. Suppl. 2001, 58, 301-311.

66. Kawano, N.; Yoshida, M. Semen-coagulating protein, SVS2, in mouse seminal plasma controls sperm fertility. Biol. Reprod. 2007, 76, 353-361. [CrossRef]

67. Kawano, N.; Yoshida, K.; Iwamoto, T.; Yoshida, M. Ganglioside GM1 mediates decapacitation effects of SVS2 on murine spermatozoa. Biol. Reprod. 2008, 79, 1153-1159. [CrossRef]

68. Araki, N.; Kawano, N.; Kang, W.; Miyado, K.; Yoshida, K.; Yoshida, M. Seminal vesicle proteins SVS3 and SVS4 facilitate SVS2 effect on sperm capacitation. Reproduction 2016, 152, 313-321. [CrossRef]

69. Wu, J.; Dong, X.; Liu, K.; Xia, Y.; Wang, X.; Shen, O.; Ding, X.; Zhang, J. Association of semenogelin (SEMG) gene variants in idiopathic male infertility in Chinese-Han population. J. Toxicol. Environ. Health. A 2019, 82, 928-934. [CrossRef] 
70. Yamasaki, K.; Yoshida, K.; Yoshiike, M.; Shimada, K.; Nishiyama, H.; Takamizawa, S.; Yanagida, K.; Iwamoto, T. Relationship between Semenogelins bound to human sperm and other semen parameters and pregnancy outcomes. Basic Clin. Androl. 2017, 27, 15. [CrossRef]

71. Perez-Patino, C.; Parrilla, I.; Barranco, I.; Vergara-Barberan, M.; Simo-Alfonso, E.F.; Herrero-Martinez, J.M.; Rodriguez-Martinez, H.; Martinez, E.A.; Roca, J. New In-Depth Analytical Approach of the Porcine Seminal Plasma Proteome Reveals Potential Fertility Biomarkers. J. Proteome Res. 2018, 17, 1065-1076. [CrossRef] [PubMed]

72. Rodriguez-Martinez, H.; Kvist, U.; Ernerudh, J.; Sanz, L.; Calvete, J.J. Seminal plasma proteins: What role do they play? Am. J. Reprod. Immunol. 2011, 66 (Suppl. 1), 11-22. [CrossRef] [PubMed]

73. Brown, S.G.; Publicover, S.J.; Barratt, C.L.R.; Martins da Silva, S.J. Human sperm ion channel (dys)function: Implications for fertilization. Hum. Reprod. Update 2019, 25, 758-776. [CrossRef]

74. Ren, D.; Navarro, B.; Perez, G.; Jackson, A.C.; Hsu, S.; Shi, Q.; Tilly, J.L.; Clapham, D.E. A sperm ion channel required for sperm motility and male fertility. Nature 2001, 413, 603-609. [CrossRef] [PubMed]

75. Qi, H.; Moran, M.M.; Navarro, B.; Chong, J.A.; Krapivinsky, G.; Krapivinsky, L.; Kirichok, Y.; Ramsey, I.S.; Quill, T.A.; Clapham, D.E. All four CatSper ion channel proteins are required for male fertility and sperm cell hyperactivated motility. Proc. Natl. Acad. Sci. USA 2007, 104, 1219-1223. [CrossRef] [PubMed]

76. Weigel Munoz, M.; Battistone, M.A.; Carvajal, G.; Maldera, J.A.; Curci, L.; Torres, P.; Lombardo, D.; Pignataro, O.P.; Da Ros, V.G.; Cuasnicu, P.S. Influence of the genetic background on the reproductive phenotype of mice lacking Cysteine-Rich Secretory Protein 1 (CRISP1). Biol. Reprod. 2018, 99, 373-383. [CrossRef]

77. Nixon, B.; MacIntyre, D.A.; Mitchell, L.A.; Gibbs, G.M.; O’Bryan, M.; Aitken, R.J. The identification of mouse sperm-surface-associated proteins and characterization of their ability to act as decapacitation factors. Biol. Reprod. 2006, 74, 275-287. [CrossRef]

78. Cohen, D.J.; Maldera, J.A.; Vasen, G.; Ernesto, J.I.; Munoz, M.W.; Battistone, M.A.; Cuasnicu, P.S. Epididymal protein CRISP1 plays different roles during the fertilization process. J. Androl. 2011, 32, 672-678. [CrossRef]

79. Roberts, K.P.; Wamstad, J.A.; Ensrud, K.M.; Hamilton, D.W. Inhibition of capacitation-associated tyrosine phosphorylation signaling in rat sperm by epididymal protein Crisp-1. Biol. Reprod. 2003, 69, 572-581. [CrossRef]

80. Roberts, K.P.; Ensrud, K.M.; Wooters, J.L.; Nolan, M.A.; Johnston, D.S.; Hamilton, D.W. Epididymal secreted protein Crisp-1 and sperm function. Mol. Cell. Endocrinol. 2006, 250, 122-127. [CrossRef]

81. Carvajal, G.; Brukman, N.G.; Weigel Munoz, M.; Battistone, M.A.; Guazzone, V.A.; Ikawa, M.; Haruhiko, M.; Lustig, L.; Breton, S.; Cuasnicu, P.S. Impaired male fertility and abnormal epididymal epithelium differentiation in mice lacking CRISP1 and CRISP4. Sci. Rep. 2018, 8, 17531. [CrossRef] [PubMed]

82. Ernesto, J.I.; Weigel Munoz, M.; Battistone, M.A.; Vasen, G.; Martinez-Lopez, P.; Orta, G.; Figueiras-Fierro, D.; De la Vega-Beltran, J.L.; Moreno, I.A.; Guidobaldi, H.A.; et al. CRISP1 as a novel CatSper regulator that modulates sperm motility and orientation during fertilization. J. Cell Biol. 2015, 210, 1213-1224. [CrossRef] [PubMed]

83. Burnett, L.A.; Washburn, C.A.; Sugiyama, H.; Xiang, X.; Olson, J.H.; Al-Anzi, B.; Bieber, A.L.; Chandler, D.E. Allurin, an amphibian sperm chemoattractant having implications for mammalian sperm physiology. Int. Rev. Cell Mol. Biol. 2012, 295, 1-61. [PubMed]

84. Da Ros, V.G.; Maldera, J.A.; Willis, W.D.; Cohen, D.J.; Goulding, E.H.; Gelman, D.M.; Rubinstein, M.; Eddy, E.M.; Cuasnicu, P.S. Impaired sperm fertilizing ability in mice lacking Cysteine-RIch Secretory Protein 1 (CRISP1). Dev. Biol. 2008, 320, 12-18. [CrossRef]

85. Cohen, D.J.; Busso, D.; Da Ros, V.; Ellerman, D.A.; Maldera, J.A.; Goldweic, N.; Cuasnicu, P.S. Participation of cysteine-rich secretory proteins (CRISP) in mammalian sperm-egg interaction. Int. J. Dev. Biol. 2008, 52, 737-742. [CrossRef]

86. Krutskikh, A.; Poliandri, A.; Cabrera-Sharp, V.; Dacheux, J.L.; Poutanen, M.; Huhtaniemi, I. Epididymal protein Rnase10 is required for post-testicular sperm maturation and male fertility. FASEB J. Off. Publ. Fed. Am. Soc. Exp. Biol. 2012, 26, 4198-4209. [CrossRef]

87. Rodriguez-Martinez, H.; Saravia, F.; Wallgren, M.; Tienthai, P.; Johannisson, A.; Vazquez, J.M.; Martinez, E.; Roca, J.; Sanz, L.; Calvete, J.J. Boar spermatozoa in the oviduct. Theriogenology 2005, 63, 514-535. [CrossRef] 
88. Lopez-Ubeda, R.; Garcia-Vazquez, F.A.; Romar, R.; Gadea, J.; Munoz, M.; Hunter, R.H.F.; Coy, P. Oviductal Transcriptome Is Modified after Insemination during Spontaneous Ovulation in the Sow. PLoS ONE 2015, 10, e0130128. [CrossRef]

89. Terada, K.; Yomogida, K.; Imai, T.; Kiyonari, H.; Takeda, N.; Kadomatsu, T.; Yano, M.; Aizawa, S.; Mori, M. A type I DnaJ homolog, DjA1, regulates androgen receptor signaling and spermatogenesis. EMBO J. 2005, 24, 611-622. [CrossRef]

90. Panneerdoss, S.; Siva, A.B.; Kameshwari, D.B.; Rangaraj, N.; Shivaji, S. Association of lactate, intracellular $\mathrm{pH}$, and intracellular calcium during capacitation and acrosome reaction: Contribution of hamster sperm dihydrolipoamide dehydrogenase, the E3 subunit of pyruvate dehydrogenase complex. J. Androl. 2012, 33, 699-710. [CrossRef]

91. Xiong, Z.; Zhang, H.; Huang, B.; Liu, Q.; Wang, Y.; Shi, D.; Li, X. Expression pattern of prohibitin, capping actin protein of muscle Z-line beta subunit and tektin-2 gene in Murrah buffalo sperm and its relationship with sperm motility. Asian-Australas. J. Anim. Sci. 2018, 31, 1729-1737. [CrossRef] [PubMed]

92. Landers, E.A.; Burkin, H.R.; Bleck, G.T.; Howell-Skalla, L.; Miller, D.J. Porcine beta1,4-galactosyltransferase-I sequence and expression. Reprod. Domest. Anim. 2009, 44, 228-234. [CrossRef] [PubMed]

93. Redgrove, K.A.; Anderson, A.L.; Dun, M.D.; McLaughlin, E.A.; O’Bryan, M.K.; Aitken, R.J.; Nixon, B. Involvement of multimeric protein complexes in mediating the capacitation-dependent binding of human spermatozoa to homologous zonae pellucidae. Dev. Biol. 2011, 356, 460-474. [CrossRef] [PubMed]

94. Avella, M.A.; Baibakov, B.; Dean, J. A single domain of the ZP2 zona pellucida protein mediates gamete recognition in mice and humans. J. Cell Biol. 2014, 205, 801-809. [CrossRef] [PubMed]

95. Ohto, U.; Ishida, H.; Krayukhina, E.; Uchiyama, S.; Inoue, N.; Shimizu, T. Structure of IZUMO1-JUNO reveals sperm-oocyte recognition during mammalian fertilization. Nature 2016, 534, 566-569. [CrossRef]

96. Caballero, I.; Vazquez, J.M.; Gil, M.A.; Calvete, J.J.; Roca, J.; Sanz, L.; Parrilla, I.; Garcia, E.M.; Rodriguez-Martinez, H.; Martinez, E.A. Does seminal plasma PSP-I/PSP-II spermadhesin modulate the ability of boar spermatozoa to penetrate homologous oocytes in vitro? J. Androl. 2004, 25, 1004-1012. [CrossRef]

97. Pursel, V.G.; Johnson, L.A. Freezing of boar spermatozoa: Fertilizing capacity with concentrated semen and a new thawing procedure. J. Anim. Sci. 1975, 40, 99-102. [CrossRef]

98. Benjamini, Y.; Hochberg, Y. Controlling the False Discovery Rate: A Practical and Powerful Approach to Multiple Testing. J. R. Stat. Soc. Ser. B 1995, 57, 289-300. [CrossRef]

99. UniProt: A hub for protein information. Nucleic Acids Res. 2015, 43, D204-D212. [CrossRef]

100. Bindea, G.; Mlecnik, B.; Hackl, H.; Charoentong, P.; Tosolini, M.; Kirilovsky, A.; Fridman, W.-H.; Pages, F.; Trajanoski, Z.; Galon, J. ClueGO: A Cytoscape plug-in to decipher functionally grouped gene ontology and pathway annotation networks. Bioinformatics 2009, 25, 1091-1093. [CrossRef] 